\title{
Correction to: Evaluating the performance of ACR, SLICC and EULAR/ACR classification criteria in childhood onset systemic lupus erythematosus
}

\author{
Reem Abdwani ${ }^{1 *}$, Eman Al Masroori ${ }^{1}$, Eiman Abdullah', Safiya Al Abrawi ${ }^{2}$ and Ibrahim Al-Zakwani $i^{3,4}$
}

Correction to: Pediatr Rheumatol 19, 141 (2021)

https://doi.org/10.1186/s12969-021-00619-w

Following publication of the original article [1], the author identified an error in the author name of Eman Al Masroori.

- The incorrect author name is: Eiman Masroori

- The correct author name is: Eman Al Masroori

The author group has been updated above and the original article [1] has been corrected.

\section{Author details}

'Department of Child Health, College of Medicine \& Health Sciences, Sultan Qaboos University, Muscat, Oman. ${ }^{2}$ Department of Pediatrics, Royal Hospital, Muscat, Oman. ${ }^{3}$ Department of Pharmacology \& Clinical Pharmacy, College of Medicine \& Health Sciences, Sultan Qaboos University, Muscat, Oman.

${ }^{4}$ Gulf Health Research, Muscat, Oman.

Published online: 02 December 2021

\section{Reference}

1. Abdwani R, Masroori E, Abdullah E, et al. Evaluating the performance of ACR, SLICC and EULAR/ACR classification criteria in childhood onset systemic lupus erythematosus. Pediatr Rheumatol. 2021;19:141. https://doi. org/10.1186/s12969-021-00619-w.

The original article can be found online at https://doi.org/10.1186/s12969021-00619-w.

* Correspondence: rabdwani@squ.edu.om

${ }^{1}$ Department of Child Health, College of Medicine \& Health Sciences, Sultan Qaboos University, Muscat, Oman

Full list of author information is available at the end of the article

(c) The Author(s). 2021 Open Access This article is licensed under a Creative Commons Attribution 4.0 International License, which permits use, sharing, adaptation, distribution and reproduction in any medium or format, as long as you give appropriate credit to the original author(s) and the source, provide a link to the Creative Commons licence, and indicate if changes were made. The images or other third party material in this article are included in the article's Creative Commons. licence, unless indicated otherwise in a credit line to the material. If material is not included in the article's Creative Commons licence and your intended use is not permitted by statutory regulation or exceeds the permitted use, you will need to obtain permission directly from the copyright holder. To view a copy of this licence, visit http://creativecommons.org/licenses/by/4.0/ The Creative Commons Public Domain Dedication waiver (http://creativecommons.org/publicdomain/zero/1.0/) applies to the data made available in this article, unless otherwise stated in a credit line to the data. 